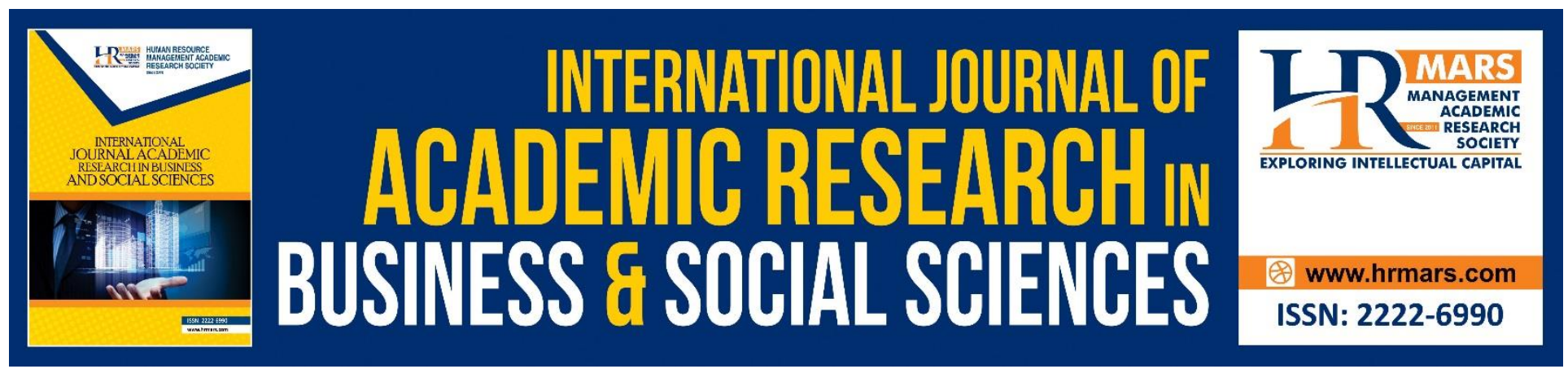

\title{
Effects of Internal Audit Committee Size on Profitability
}

\author{
James Commey, Wisdom Osabutey, Linda Afoley
}

To Link this Article: http://dx.doi.org/10.6007/IJARBSS/v10-i5/7189

DOI:10.6007/IJARBSS/v10-i5/7189

Received: 08 March 2020, Revised: 10 April 2020, Accepted: 25 April 2020

Published Online: 08 May 2020

In-Text Citation: (Commey et al., 2020)

To Cite this Article: Commey, J., Osabutey, W., \& Afoley, L. (2020). Effects of Internal Audit Committee Size on Profitability. International Journal of Academic Research in Business and Social Sciences, 10(5), 221-228.

Copyright: (C) 2020 The Author(s)

Published by Human Resource Management Academic Research Society (www.hrmars.com)

This article is published under the Creative Commons Attribution (CC BY 4.0) license. Anyone may reproduce, distribute, translate and create derivative works of this article (for both commercial and non-commercial purposes), subject to full attribution to the original publication and authors. The full terms of this license may be seen at: http://creativecommons.org/licences/by/4.0/legalcode

Vol. 10, No. 5, 2020, Pg. 221 - 228

http://hrmars.com/index.php/pages/detail/IJARBSS

JOURNAL HOMEPAGE

Full Terms \& Conditions of access and use can be found at http://hrmars.com/index.php/pages/detail/publication-ethics 


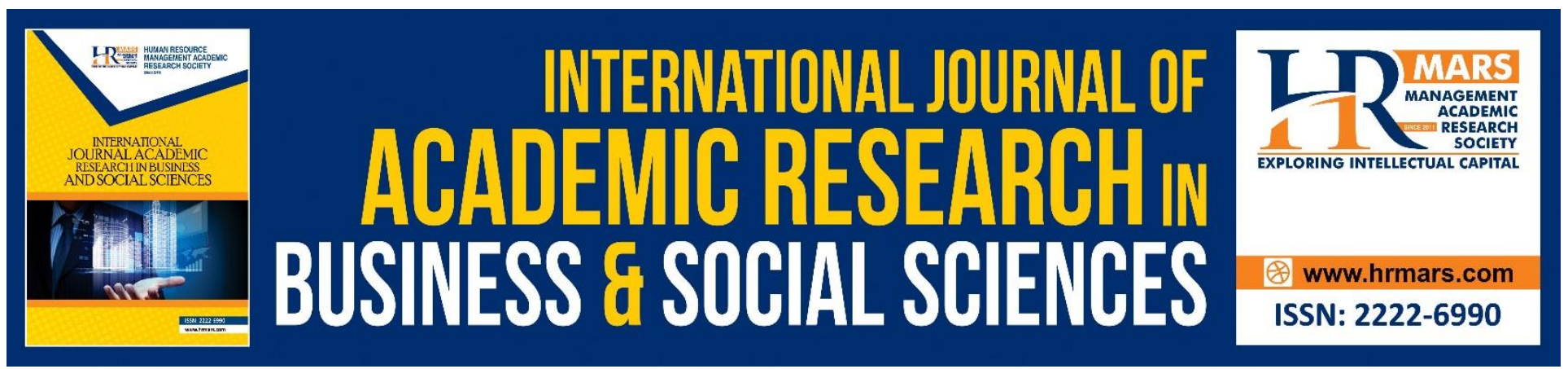

\title{
Effects of Internal Audit Committee Size on Profitability
}

\author{
James Commey ${ }^{\mathrm{b}}$, Wisdom Osabutey ${ }^{\mathrm{a}}$, Linda Afoley ${ }^{\mathrm{a}}$ \\ aZhejiang Gongshang University, Xiasha Educational District, Hangzhou, China, ${ }^{b}$ University of \\ Professional Studies-Accra, Ghana (UPSA)
}

\begin{abstract}
Business companies around the world need to develop and grow continuously by acquiring new investments but a business company without an audit committee or audit department is just like a nation without law enforcing agents. To examine the developed model, the data were obtained through a field survey from some of the selected firms in Accra, Ghana. Linear regression model were developed to analyse this paper. In terms of audit committee size (ACSIZE), the result shows a negative relationship with ROA, but significant. Also firm size (SIZE) has a positive significant relationship with (ROA). The variable that measures audit committee independence (ACIND) showed a negative significant relationship between audit committee independence and (ROA). ACMEET and AGE were insignificant to (ROA).
\end{abstract}

Keywords: Audit Committee Independence (ACIND), Return on Assets (ROA), Size of Audit Committee (ACSIZE).

\section{Introduction}

Business companies around the world need to develop and grow continuously by acquiring new investments, but potential investors often need to ensure that the business environment is stable and safe and that they can generate long-term profits (Oroud, 2019). Effective corporate governance has been identified to be critical to all economic transactions especially in emerging and transition economies (Kyereboah-Coleman, 2008). However, the role of internal audit committee in that corporate organization is critical for the corporate overall performance. An audit is an independent examination of financial information of an organization (Arshad, Satar, Hussain, 2011). Its service helps us to detect errors and frauds at early stage and gives true views about financial information, either its performed by internal audit committee or external audit committee (Arshad, Satar, Hussain, 2011). According to Kyereboah-Coleman (2008) Corporate governance is the "ways of bringing the interests of investors and managers into line and ensuring that firms are run for the benefit of investors". This means, the performance is a critically require as a work or assurance for the investors. The primary roles of the audit committee include overseeing the financial reporting process and to monitor the management, because management intends to manipulate figures for their own interest (Al-Mamun, Yasser, Rahman, Wickramasinghe, \& Nathan, 2014). Audit committee is one of the main elements of the corporate governance helping to control management practices (Oroud, 2019). In addition, audit committees help to improve the quality of financial reports and reduce audit risk 
(Oroud, 2019). The audit committees play an important role in supervising and monitoring the management of the company in order to protect the interests of the owners (Oroud, 2019). According to (Salloum, Azzi, \& Gebrayel, 2014) Audit Committee is to assist the board of directors in effective management monitoring with the aim to protect the interest of the shareholders. The audit committee is a critical link between a firm's financial reporting function and its external shareholders. When this link is compromised, it can lead to even larger corporate governance failures (Arshad, Satar, Hussain, 2011). The East Asian crisis and the recent corporate scandals around the world coupled with the seemingly poor performance of corporate Africa have given prominence and impetus to corporate governance on the continent (Kyereboah-Coleman, 2008). In Ghana, Internal Audit Agency Act, 2003 was established with the objectives to co-ordinate, facilitate and provide quality assurance for internal audit activities within the Government Ministries, Departments and Agencies and the Metropolitan, Municipal and District Assemblies (Act, 2003). The Ghana Audit Service has set the following core functions; To ensure that the auditing activities of the Audit Service as spelt out in the Audit Service Act and carried out in accordance with best international practices and monitor the use and management of all public funds and report to Parliament this covers, Constitutional, statutory and any other body or organization established by an Act of parliament. Ensure effective implementation of the Assets \& Liabilities regime (Based \& Estimates, 2019). It's clear from the above mentioned core functions of the Ghana Audit service, doesn't include private corporate entities in Ghana.

Based on the previous studies results and some assumption theories, the following research objectives were formulated

$>$ To examine significant relationship between audit committee size and company's profitability.

$>$ To examine the characteristics of audit committee of listed firms in Ghana.

$>$ To ascertain the efficiency of the audit committees of listed firms in Ghana.

$>$ To ascertain the relationship between audit committee effectiveness and performance of listed firms in Ghana.

According to (Baccouche, Hadriche, \& Omri, 2013), a large literature focused on the concept of multiple directorship by directors and its relationships with internal and external characteristics of the firm. In this framework, some studies highlighted the benefits of increasing the number of directorships held by directors (e.g., additional experience; firm legitimacy)(Baccouche et al., 2013).

\section{Methods and Materials Used}

Audit Committee effectiveness were measured by the characteristics of the audit committee and the performance of the listed firms measured by return on assets (ROA). The model treated performance of the listed firms as the dependent variable while the independent variables were the Audit committee effectiveness which included Audit Independence, Audit meeting, and Audit size. This paper is based on panel data, hence a linear regression model of firm performance versus effectiveness of audit committee was applied to examine the performance of firms. This model considered firm performance as the dependent variable while the independent variables is the effectiveness of audit committee represented by their characteristics which includes; Audit committee Independence, frequency of audit committee meetings and the size of audit committee. The relationship equation represented in the linear equation below. 
INTERNATIONAL JOURNAL OF ACADEMIC RESEARCH IN BUSINESS AND SOCIAL SCIENCES

Vol. 10, No. 5, May, 2020, E-ISSN: 2222-6990 @ 2020 HRMARS

$Y=\alpha+\beta X 1+e_{i t}$

Where, $Y$ represents the dependent variable. $\alpha$ is constant, $B$ is the coefficient of the explanatory variable (audit committee effectiveness), $\beta X 1$ is the independent variable and $e_{i t}$ is the error term.

Representing equation (1) above in an econometric model, equation (2) below therefore becomes: $R O A_{i t}=\beta_{0}+\beta_{1} A C I N D_{i t}+\beta_{2} A C M E E T_{i t}+\beta_{3} A C S I Z E_{i t}+\beta_{4} S I Z E_{i t}+\beta_{5} A G E_{i t}+e_{i t}$

Where subscript $\mathrm{i}$ and $\mathrm{t}$ represent listed firms and time, respectively. $\mathrm{Y}$ represents (the performance of Audit Committees and is measured by return on assets (ROA).

ACIND = Audit committee independence, measured as the ratio of Non-Executive Committee members to audit committee size.

ACMEET = Frequency of audit committee meeting is measured by the frequency of their meetings.

ACSIZE = Audit committee size measured by the number of members in the audit committee.

SIZE $=$ Size of the firm measured as log of total assets.

$A G E=$ Age of the firm measured as the age of the firm.

\section{Results}

Audit committee effectiveness was examined first by considering the size of audit committee (ACSIZE). The results suggest that the average audit committee size is about four directors with a minimum of three and maximum of seven directors and meet 4.4 times per year. Listed firms in Ghana are required to have at least 3 independent directors. Reflecting this requirement for the composition of audit committees, the mean number of non-executive members on the board is 3 .

However, the results reveals that, of the firms studied the return rate measured by return on asset (ROA) is approximately $3 \%$. This indicate that on the average mean for every $100 \%$ worth of total assets of the firms, $3 \%$ was earned as profit after tax This shows that management is employing the firm's total assets to make profit during the period under review. Again the average age of listed firms in Ghana is 38.26 years. This shows that listed firms in Ghana are longstanding which makes them efficient. The growth in age has an influence on profits because of the cumulative experience of the firm and the generation of purchasing power. And according to the experience curve, the firm benefits from economies of scale and experienced performance among its life. So older firms are expected to put up a healthy performance.

Table 3.1 as shown below is the descriptive statistics. It shows

Table 3.1 Descriptive Statistics

\begin{tabular}{lccccc}
\hline Variable & Mean & Std. Dev. & Min. & Max. & Obs \\
ROA & .33 & 0.14 & -.63 & 0.55 & 125 \\
ACSIZE & 4.54 & 1.11 & 3 & 7 & 125 \\
ACMEET & 4.42 & 1.09 & 2 & 10 & 125 \\
ACIND & 3.24 & 1.08 & 1 & 6 & 125 \\
SIZE & 7.96 & 1.10 & 610 & \multicolumn{2}{c}{125} \\
AGE & 38.26 & 22.26 & 6 & 118 & 125 \\
\hline
\end{tabular}

Where $R O A_{i t}$ is used for the performance of the listed firms. It is measured by the ratio of profit after tax to total assets. ACIND $D_{i t}$ is the audit committee independence, measured as the ratio of nonexecutive committee members to audit committee size. ACMEET it is the number of times the audit committee meet and is measured by the frequency of their meetings? ACSIZE is the audit committee 
INTERNATIONAL JOURNAL OF ACADEMIC RESEARCH IN BUSINESS AND SOCIAL SCIENCES Vol. 10, No. 5, May, 2020, E-ISSN: 2222-6990 @ 2020 HRMARS

size measured by the number of members on the committee? SIZE $E_{i t}$ is the size of the firm measured as $\log$ of total assets? $A G E_{i t}$ is the age of the firm measured as the day of existence till now?

\section{Correlation Matrix Showing the Relationship between the Various Variables}

Table 2 provide correlation coefficient between the variables of the study. The results suggest that Audit Committee Size (ACSIZE) has negative weak relationship with Return on Asset (ROA). Audit Committee Meeting has a negative weak relationship with Return on Asset (ROA). This means that the audit committees with fewer numbers of meetings are inactive and are unlikely to supervise management effectively. Therefore audit committees cannot oversee the financial reporting process, identify management risk and monitor internal controls. Beasley et al. (2000) found that fraudulent firms with earning misstatements have fewer audit committee meetings than non-fraud firms. Audit Committee Independence (ACIND) has a weak negative relationship with Audit Committee meeting (ACMEET) and Audit Committee Size (ACSIZE) which is significant. This means that not all member does take part in the critical decisions that will checkmate the excesses of management and misleading auditors report. Size is positively related to ROA, ACSIZE, and ACIND this indicates that larger firms have the ability to push managers to pursue lower costs of debt and increase performance. This gives the firm operational advantages over its inexperienced counterparts and also improve its reputation and enhance customer loyalty. Age is positively related to ACMEET.

In order to test for multicollinearity, the study adopted the threshold of 0.8 from prior studies. Hogan et al (2008) suggest 0.8 as the beginning of the correlation level at which multicollinearity negatively affect the regression analysis. The correlation matrix in Table 2 shows that the maximum absolute value among the correlation coefficients is -0.3548 between ACSIZE and ACIND. This is below the threshold of 0.8 proposed by Hogan et al (2008) for evidence of severe multicollinearity.

Table 3.2 Correlation matrix

\begin{tabular}{lllllll}
\hline & ROA & ACSIZE & ACMEET & ACIND & SIZE & AGE \\
\hline ROA & 1.0000 & & & & & \\
ACSIZE & $-0.2609^{*}$ & 1.0000 & & & & \\
ACMEET & -0.0455 & 0.1612 & 1.0000 & & & \\
ACIND & 0.0492 & $-0.3548^{*}$ & -0.0250 & 1.0000 & & \\
SIZE & $0.1996^{*}$ & $0.2151^{*}$ & -0.1206 & $-0.4136^{*}$ & 1.0000 & \\
AGE & -0.0858 & -0.0769 & $0.2002^{*}$ & 0.0622 & -0.0117 & 1.0000
\end{tabular}

*Significant at 5\%

\section{Regression Analysis}

Table 3.2 contains the results of the regression analysis that examines the effectiveness of audit committees on performance of listed firms. In terms of audit committee size (ACSIZE), the result shows a negative relationship with ROA, but significant. This means that members can bring more resources to the firm, such as experience and expertise, which contribute to the audit committee's effectiveness in monitoring management, hence leading to performance. This means that, in cases where the audit committee are large, it suffers from the problem of free riders and a higher probability of members are more vulnerable to the pressures and more subject to follow other members' opinion without giving another argument. 
Also, firm size (SIZE) has a positive significant relationship with (ROA). This implies that, if a firm grows in size the profitability of the firm will rise. Possible reasons for such a size-profit behaviour is that, higher profitability of large firms can be due to market power, economies of scale and market experience.

The variable that measures audit committee independence (ACIND) showed a negative significant relationship between audit committee independence and (ROA). The unexpected revelation that audit committee independence has negative and significant influence on firm performance leaves much to be desired of the selection and composition process of audit committees in listed firms in Ghana. In particular, it is indicative that the requirement that audit committee be made up of shareholders and directors with majority being NEDs has not help to achieve true independence that enhances performance. Furthermore, the result is suggestive that the selection of persons into the audit committee is masterminded by the CEOs

However, ACMEET and AGE were insignificant to (ROA). The possible explanation might be due to the fact that higher ownership concentration affects directors' independence and leads to ineffective audit committee meetings.

Table 3.3 Correlated Panels Corrected Standard Errors Regression Results

\begin{tabular}{|c|c|c|c|c|}
\hline \multirow[b]{2}{*}{ Variable } & \multicolumn{3}{|c|}{ ROA } & \multirow[b]{2}{*}{ Std Error } \\
\hline & \multirow{2}{*}{\multicolumn{2}{|c|}{$\begin{array}{l}\text { Coef } \\
-0.06\end{array}$}} & Sig & \\
\hline$\overline{\text { ACSIZE }}$ & & & 0.00 & 0.02 \\
\hline ACMEET & & 0.01 & 0.12 & 0.01 \\
\hline ACIND & -0.14 & & 0.00 & 0.04 \\
\hline Size & & 0.06 & 0.00 & 0.01 \\
\hline Age & & -0.00 & 0.10 & 0.00 \\
\hline Constant & & -0.06 & 0.50 & 0.09 \\
\hline R-squared & $=0.2045$ & & & \\
\hline Wald chi2 (5) & $=64.38$ & & & \\
\hline Prob > chi2 & $=0.0000$ & & & \\
\hline Number of $\mathrm{Ob}$ & servation $=1$ & 25 & & \\
\hline
\end{tabular}

Where $R O A_{i t}$ is used for the performance of the listed firms. It is measured by the ratio of profit after tax to total assets. ACIND $D_{i t}$ is the audit committee independence, measured as the ratio of nonexecutive committee members to audit committee size. ACMEET $i$ is the number of times the audit committee meet and is measured by the frequency of their meetings. ACSIZE is the audit committee size measured by the number of members on the committee. SIZ $E_{i t}$ is the size of the firm measured as log of total assets. $A G E_{i t}$ is the age of the firm measured as the day of existence till now.

It is important to note that the R-Squared value is around $20.5 \%$ indicating that only $20.5 \%$ of the variations in ROA is attributable by the audit committee characteristics used in the regression namely: ACSIZE, ACMEET, and ACIND.

\section{Conclusion}

The results of the study have shown a negative and significant effect between the number of independent auditors and firm performance. It is generally believed that an increase in the number of independent directors leads to better financial monitoring and reporting which are of essence in improving firm performance. However, the negative association between the number of 
independent auditors and firm performance has shed new light onto the existing body of literature since prior studies have shown a positive association between the two variables (Abbott et al. 2000). The findings of the study have also shown that the audit committee size is negatively associated with firm performance. With increased size of the audit committee, firm performance is expected to decline because of the problem of free riders and the pressure to follow other members' opinion without considering your argument. However, it can also be argued that large size audit committees can protect and control the process of accounting and finance since there is increased expert advice with increased size of the audit committee.

Moreover, we find evidence that audit committee meeting has a positive relationship with performance. This indicates that board diligence can improve the efficiency of performance of firms because the audit committee has more opportunities to monitor management performance which reduces the possibility of fraud.

\section{Recommendations}

There is need for firms to have an audit committee, that is not too small such that there is lack of expert advice and too large so that it has free riders that are prone to follow other members opinion. The size of the audit committee should also be in a way that the process of accounting and finance are protected and firm performance is increased.

The study has established that the number of independent auditors has a negative influence on firm performance. However, there is need to increase the proportion of independent auditors since an increase in their number reduces the chances of financial misreporting and leads to positive perception by investors. In so doing, there is improved firm performance. Moreover, in order to reduce financial distress in a company there is also need to increase the number of independent directors because they are independent and without influence from the directors.

Future studies, should consider more factors like, committee gender diversity, audit committee financial expertise, audit committee tenure and other variables such as audit committee composition that can influence firm's financial performance.

\section{Acknowledgments}

This research was financially supported by Philosophy and Social Sciences Study Foundation of Zhejiang Province (No.18NDJC196YB) and Zhejiang Business Research Centre Foundation (No.17ZSJD04YB). The authors are thankful to college of economic and college of public administration of Zhejiang GongShang University for their assistance and encouragement.

\section{Author Contributions}

Conception or design of the work: W. Osabutey, I. Ofoeda, J. Commey, L.Afoley Data Collection: I. Ofoeda, L.Afoley W. Osabutey J. Commey, I. Ofoeda, Data Analysis and Interpretation W. Osabutey, I. Ofoeda, . Drafting the article: W. Osabutey, J. Commey, I. Ofoeda Final Proof Reading: I. Ofoeda, W. Osabutey

\section{Conflict of Interest}

W. Osabutey, , I. Ofoeda , J. Commey, L.Afoley certify that they have NO affiliations with or involvement in any organization or entity with any financial interest (such as honoraria; educational grants; participation in speakers bureaus; membership, employment, consultancies, stock 
INTERNATIONAL JOURNAL OF ACADEMIC RESEARCH IN BUSINESS AND SOCIAL SCIENCES

Vol. 10, No. 5, May, 2020, E-ISSN: 2222-6990 @ 2020 HRMARS

ownership, or other equity interest; and expert testimony or patent-licensing arrangements), or nonfinancial interest (such as personal or professional relationships, affiliations, knowledge or beliefs) in the subject matter or materials discussed in this manuscript.

\section{References}

Act, A. (2003). Act, 20032003.

Al-Mamun, A., Yasser, Q. R., Rahman, M. A., Wickramasinghe, A., \& Nathan, T. M. (2014).

Relationship between audit committee characteristics, external auditors and economic value added (EVA) of public listed firms in Malaysia. Corporate Ownership and Control, 12(1CONT9), 899-910. https://doi.org/10.22495/cocv12i1c9p12

Arshad, S., Hussain, N. (2011). Effect of Audit on Profitability: A Study of Cement Listed Firms, Pakistan. Global Journal of Management and Business Research, 11(9), 2249-4588.

Baccouche, S., Hadriche, M., \& Omri, A. (2013). The impact of Audit Committee MultipleDirectorships on earnings management: Evidence from France. Journal of Applied Business Research, 29(5), 1333-1342. https://doi.org/10.19030/jabr.v29i5.8017

Based, P., \& Estimates, B. (2019). Audit service of ghana.

Kyereboah-Coleman, A. (2008). Corporate governance and firm performance in Africa: A dynamic panel data analysis. Journal for Studies in Economics and Econometrics, 32(2), 1-24.

Oroud, Y. (2019). The Effect of Audit Committee Characteristics on the Profitability: Panel Data Evidence. International Journal of Economics and Finance, 11(4), 104. https://doi.org/10.5539/ijef.v11n4p104

Salloum, C., Azzi, G., \& Gebrayel, E. (2014). Audit Committee and Financial Distress in the Middle East Context: Evidence of the Lebanese Financial Institutions. International Strategic Management Review, 2(1), 39-45. https://doi.org/10.1016/j.ism.2014.09.001

Act, A. (2003). Act, 20032003.

Al-Mamun, A., Yasser, Q. R., Rahman, M. A., Wickramasinghe, A., \& Nathan, T. M. (2014). Relationship between audit committee characteristics, external auditors and economic value added (EVA) of public listed firms in Malaysia. Corporate Ownership and Control, 12(1CONT9), 899-910. https://doi.org/10.22495/cocv12i1c9p12

Arshad, S., Hussain, N. (2011). Effect of Audit on Profitability: A Study of Cement Listed Firms, Pakistan. Global Journal of Management and Business Research, 11(9), 2249-4588.

Baccouche, S., Hadriche, M., \& Omri, A. (2013). The impact of Audit Committee MultipleDirectorships on earnings management: Evidence from France. Journal of Applied Business Research, 29(5), 1333-1342. https://doi.org/10.19030/jabr.v29i5.8017

Based, P., \& Estimates, B. (2019). Audit service of ghana.

Kyereboah-Coleman, A. (2008). Corporate governance and firm performance in Africa: A dynamic panel data analysis. Journal for Studies in Economics and Econometrics, 32(2), 1-24.

Oroud, Y. (2019). The Effect of Audit Committee Characteristics on the Profitability: Panel Data Evidence. International Journal of Economics and Finance, 11(4), 104. https://doi.org/10.5539/ijef.v11n4p104

Salloum, C., Azzi, G., \& Gebrayel, E. (2014). Audit Committee and Financial Distress in the Middle East Context: Evidence of the Lebanese Financial Institutions. International Strategic Management Review, 2(1), 39-45. https://doi.org/10.1016/j.ism.2014.09.001. 